Annals of Warsaw University of Life Sciences - SGGW

Land Reclamation No 47 (3), 2015: 249-260

(Ann. Warsaw Univ. of Life Sci. - SGGW, Land Reclam. 47 (3), 2015)

\title{
Effects of environmental changes and human impact on the functioning of mountain river channels, Carpathians, southern Poland
}

\author{
KAZIMIERZ KRZEMIEŃ, ELŻBIETA GORCZYCA, MATEUSZ SOBUCKI, \\ MACIEJ LIRO, MICHAŁ $Ł Y P$ \\ Institute of Geography and Spatial Management \\ Jagiellonian University in Kraków
}

\begin{abstract}
Effects of environmental changes and human impact on the functioning of mountain river channels, Carpathians, southern Poland. In the northern slope of the Carpathian Mountains and in their foreland, river and stream channels have been significantly transformed by human impact. These transformations result from changing land use in river basins and direct interference with river channels (alluvia extraction, engineering infrastructure, channel straightening). Anthropogenic impacts cause significant changes in the channel system patterns leading to increased impact of erosion. This mainly leads to the channelling of the fluvial system. This article reviews studies of structure and dynamics of Carpathian river channels conducted based on the methodology of collection of data on channel systems, developed in the Department of Geomorphology of the Institute of Geography and Spatial Management, Jagiellonian University.
\end{abstract}

Key words: channel structure changes, Carpathian river channels, human impact

\section{INTRODUCTION}

The northern slope of the Carpathian Mountains is located in Southern Poland, within temperate climatic zone. Annual precipitation ranges from $800 \mathrm{~mm}$ in the foothills to $1,700 \mathrm{~mm}$ in the Tatra Mountains. During the summer and autumn months prevailing western or northwestern air atmospheric front migra- tion sometimes creates rain storms and the resultant heavy floods transform the river channels. During the winter months the low air temperatures are responsible for river icing and sometimes local ice jams formation. Snow-melting floods can also be an important agent of river channels transformations (Niedźwiedź and Obrębska-Starklowa 1991).

River channels in Poland provide an example of highly sensitive geomorphological systems. They are exposed to changes in the natural environment and human impact on catchment basins as a whole and on the channels themselves. Such developments lead to rapid changes in the structure of the entire channel systems. In the late 19th century and in the first half of the 20th century Carpathian river channels were wide, shallow and often braiding. In the Beskidy Mountains their channel bottoms were composed of coarse alluvia that formed large gravel bars and vegetated islands (Kaszowski et al. 1976, Wyżga 2008, Krzemień 2012). Present day channels are much more diverse, both in terms of their longitudinal profile and channel pattern. Their structure is characterised by a varied pattern of different morphodynamic reaches within the channel system. The diversity 
of Carpathian river channels was investigated in the scale of whole Carpathians (Klimek 1979, Starkel and Lajczak 2008) as well as chosen basins (Zawora 1967, Baumgart-Kotarba and Kotarba 1979, Krzemień 1984, Zawiejska 2006, Korpak et al. 2008, Izmaiłow et al. 2009, Gorczyca 2012, Gorczyca et al. 2013).

A study of the channel system structure requires the use of an appropriate methodological approach so that research can be carried out in a uniform manner in various areas. Investigations of the channel systems in question are needed for scientific purposes in order to determine any regularities in their development, as well as for applied purposes to help in potential river training (Krzemień 2012).

This article reviews studies of structure and dynamics of Carpathian river channels conducted based on the methodology of collection of data on channel systems. The methodology has been developed since 1970s in the Department of Geomorphology of the Institute of Geography and Spatial Management, Jagiellonian University (Kaszowski 1979, Kamykowska et al. 1999, Krzemień 2012 - Ed.).

\section{MATERIAL AND METHODS}

In investigating river channels a fieldwork protocol was used together with a manual prepared by the Department of Geomorphology of the Institute of Geography and Spatial Management, Jagiellonian University (Kamykowska et al. 1999, 2012). The study involves collecting field data about river channels and identifying regularities in the spatial patterns of their structures. It is also designed to determine the dynamic functions of river channels. The underlying assumption is that each channel system consists of specific morphostatic and morphodynamic reaches (Fig. 1.)

The existence of such reaches results from channel evolution in changing environmental conditions. The reaches make up a specific system of river channels. The structure of the Carpathian river channels is characterised by a specific sequence of morphodynamic reaches within the system (Krzemien 2012, Fig. 2 ). Determining the structure is necessary for both scientific and applied purposes.

The following regularities need to be established for scientific purposes:

- the channel system development in an investigated area;

- a change of channel morphology over time (from repeated mapping).

For applied purposes, establishing the river structure may be helpful in:

- possible channel training;

- possible channel renaturalisation;

- determining the impact of channel training;

- environmental assessment of river and stream channels.

All channel data are collected by means of the fieldwork protocol with respect to basic uniform reaches (Fig. 2). The reaches are mapped based on the channel pattern and verified through field surveys. The protocol comprises four sets of data collected mainly in the field and one set of data determined chiefly through desk studies (Fig. 2). These include: preliminary information, channel characteristics (position, geology, channel parameters, longitudinal profile and 


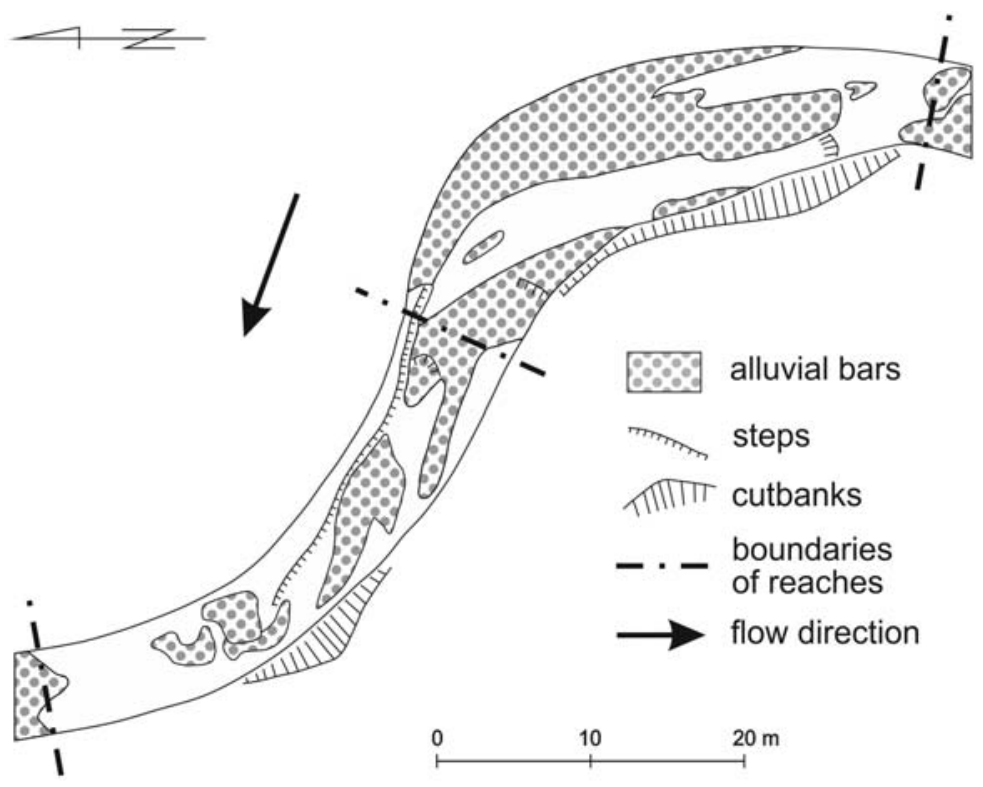

FIGURE 1. Examples of morphodynamic reaches in the channel of the Potok Biały - according to Kaszowski (1973) - as amended

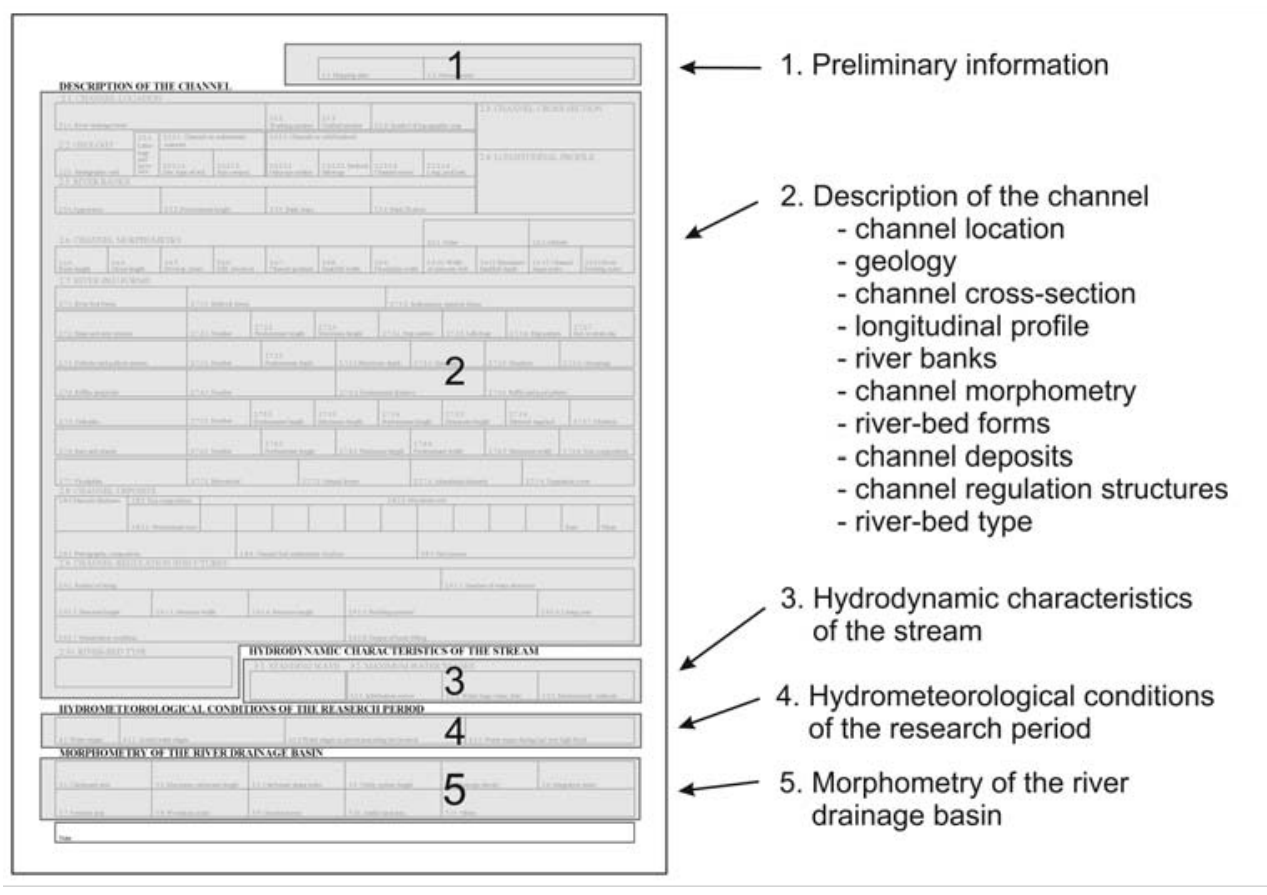

FIGURE 2. Structure of fieldwork protocol (register) for mapping river channels 
cross sections, banks, bed forms, sediments, in-channel infrastructure, channel type), hydrodynamic flow parameters and hydrometeorology characteristics in the study period. The fifth set of data comprises the characteristic of the catchment area, which is determined through desk studies. The data sheet comprises 57 items of quantitative and 48 items of qualitative data. The quantitative information is used to calculate relevant indicators that are crucial in analysing the river channel (Kamykowska et al. 2012, Łyp 2012). The fieldwork protocol is filled in according to a manual - a key containing pre-determined answers.

In parallel with the fieldwork, the research comprises the study of maps and photogrammetric data, as well as historical data about the channels themselves and their respective catchment areas. Data used includes information about: the geographical environment of the catchment area and its changes, the hydrological flow regime, in-channel infrastructures, sediment extraction and changes in the channel pattern.

Based on the collected parameters of the channel, channel forms and sediments, a typology of the river channels is then prepared (Kaszowski, Krzemień 1979, 1999, Chełmicki, Krzemień 1999, Krzemień 1999, Gorczyca 2012, Korpak 2012). The analysis of a given channel system is based on characteristics describing the channel dynamics, i.e. the processes forming and transforming the channel, either directly or indirectly. Thus in the course of the study the channel processes have often been considered the key criteria in distinguishing the individual types of channels (Krzemień 2003).

\section{RESULTS AND DISCUSSION}

Mapping of the selected Carpathian river channels allows for recognition and establishment of regularities in the development of entire channel systems. At least two major systems: denudational and fluvial ones may be distinguished in each catchment area (Wrońska-Wałach et al. 2013). Each of these systems is characterised by a specific structure, the establishment of which permits the determination of its level of complication and dynamics (Fig. 3). A number of channel structures have already been distinguished in the Polish Carpathians (see e.g. Krzemień 2003, Izmaiłow et al. 2006, Gorczyca 2012, Korpak 2012). However, the existing research is insufficient. Similarly, despite the abundance of international literature on the subject of fluvial processes, the patterns of development and the modelling of wholemountain or high-mountain fluvial systems have not been adequately investigated to date.

Morphostatic and morphodynamic reaches can be distinguished in the longitudinal profile of a river channel. The reaches make up a specific system of river channels. Introducing changes of structure within the investigated reach may result in changes in other sections, often difficult to predict. The complexity of river channels frequently results from differences in local substratum resistance. However, some areas with uniform geology also show a significant diversity of channels. The main underlying reason is the historic development of individual areas as a consequence of which the present-day rivers and streams have adjusted their longitudinal profiles and 

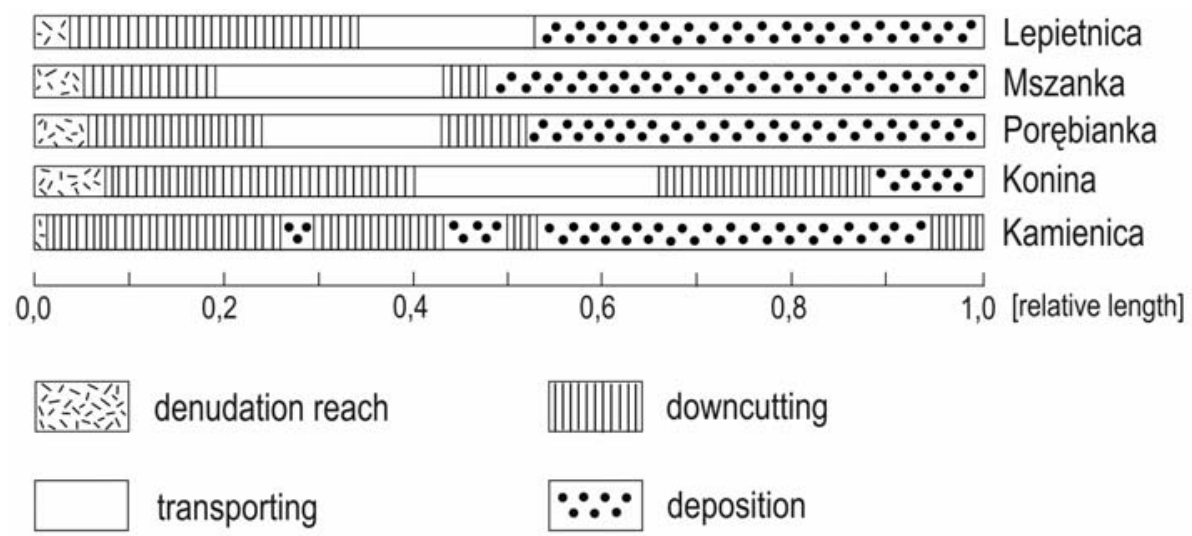

FIGURE 3. Structures of selected channels of streams in the Gorce Mountains - based on Krzemien (1984)

cross-sections to the altered hydrodynamic and morphological conditions. In many mountain areas the channel structure generally reflects key developments in the area's land relief. Such systems include, for example, channels exposed to significant human impact.

Channel systems are mainly modelled during extreme episodic discharges. Then the structure of the channel system in areas with high human impact rapidly adjusts to changing conditions on the valley floors and slopes.

Research has shown that the main reasons behind the development of river channels in the Polish part of the Carpathians in recent years include:

- changing land use in their catchment areas, notably after 1989;

- the construction of embankments;

- channel narrowing;

- channel training;

- gravel mining;

- channel straightening.

Changes in land use in the Carpathians started to take place as early as the post-war period when the local native minorities - Lemkos and Boikos were displaced from the Beskid Niski and Bieszczady Mountains (Lach 1999). Further major changes took place after 1989 following the political transformations in Poland (Fig. 4). They have been highly beneficial in reducing slope degradation. Retaining the clastic material on the slopes, on the other hand, speeds up downcutting of local streams. An overlap of the downcutting stimuli has been noted after 1989 resulting from changes in the channels themselves and those resulting from land use change (Klimek 1987, Wyżga 1991, Łapuszek, Ratomski 2006, Korpak et al. 2008).

Embankments started to be built in the 18th century to prevent flooding of vast areas on the valley floors of the upper Vistula basin during floods. It should be stressed that the flood water, tightly compressed between the embankments, often breached them in unpredictable places (Trafas 1975, Gębica et al. 1998). Efforts were put into narrowing of the flows during extreme episodes in the Carpathian river channels, especially in the foreland. According to Kaszowski et al. (1976), in the 1960s, 1-4-order streams 


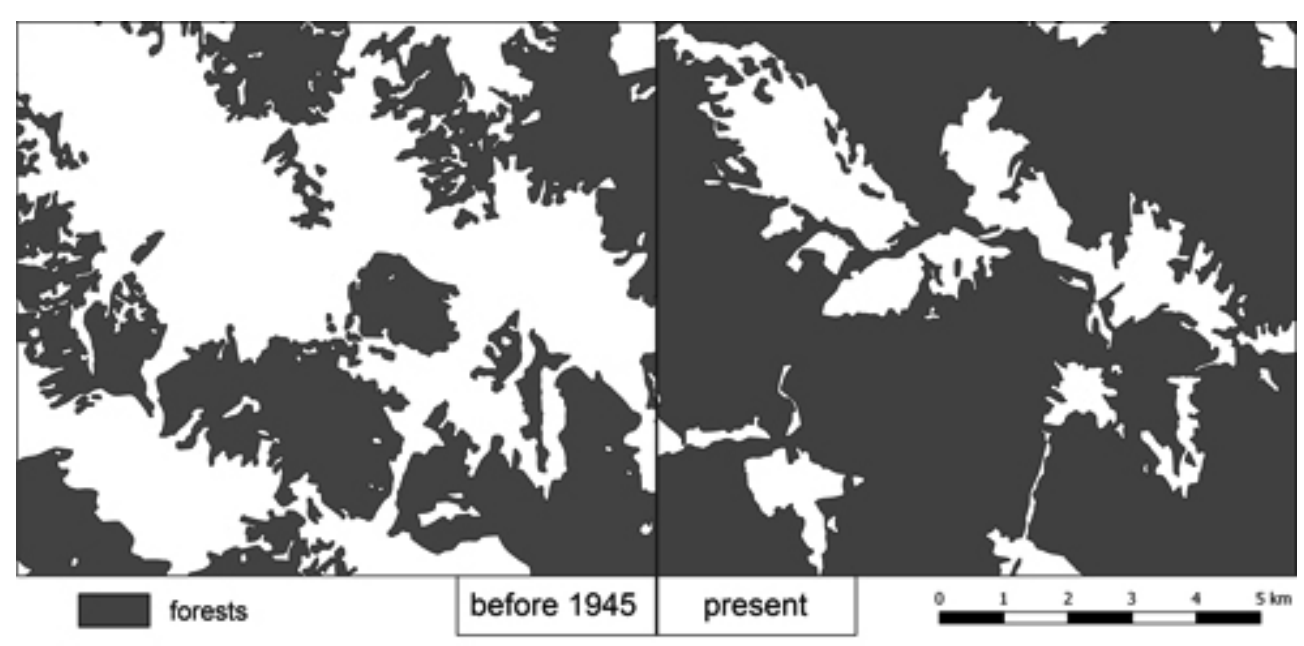

FIGURE 4. Forest cover changes in the upper Wisłoka catchment basin near Krempna

(according to the Strahler classification) were usually deepened, whereas 5-7-order streams were characterised by aggradation. The situation changed radically in the late $1980 \mathrm{~s}$ as a result of growing downcutting (Korpak et al. 2008).

Owing to river channel narrowing and training, the energy of rivers tended to gradually cumulate. The last $30-40$ years have seen major transformations of channels of all sizes. River channel regulation has proceeded in stages, from the lowest reaches upstream (Zawiejska 2006, Starkel, Łajczak 2008). Trained channels are characterised by mild curves and long straight lines (Kościelniak 2004, Korpak et al. 2008, Fig. 5). They have usually been re-directed to run in the middle of a wide gravel riverbed (Fig. 5). Several stages of river channel training may be distinguished in the Carpathians: pre-WWII, post-WWII until 1970 , 1971-1980, 1981-1990 and post-1990. The stages differ in terms of regulation methods and degree. As a result of the projects the channels have been straight- ened, narrowed, deepened, and their longitudinal profile has been changed. This has caused intensified downcutting (Soja 1977, Kościelniak 2004, Zawiejska 2006, Korpak et al. 2008).

The regulation of, i.a. the channels of the Biały Dunajec, the Czarny Dunajec, the Dunajec, the Skawa, the Mszanka, the Porebianka, and the Lososina rivers have been directed towards a single, narrow channel and the cutting off of side channels by various longitudinal structures, notably groynes and other bank protection structures (Krzemień 1984, Kościelniak 2004, Zawiejska, Krzemień 2004, Zawiejska 2006, Gorczyca 2012, Korpak 2012). The most characteristic feature of the present-day structure of large Carpathian river channels is a significant development of uniform channel geometry and its morphodynamic functions (Zawiejska, Krzemień 2004, Zawiejska 2006). This is exemplified by the channels of the Dunajec, the Mszanka and the Porębianka rivers (Kościelniak 2004, Zawiejska 2006). As a result of 


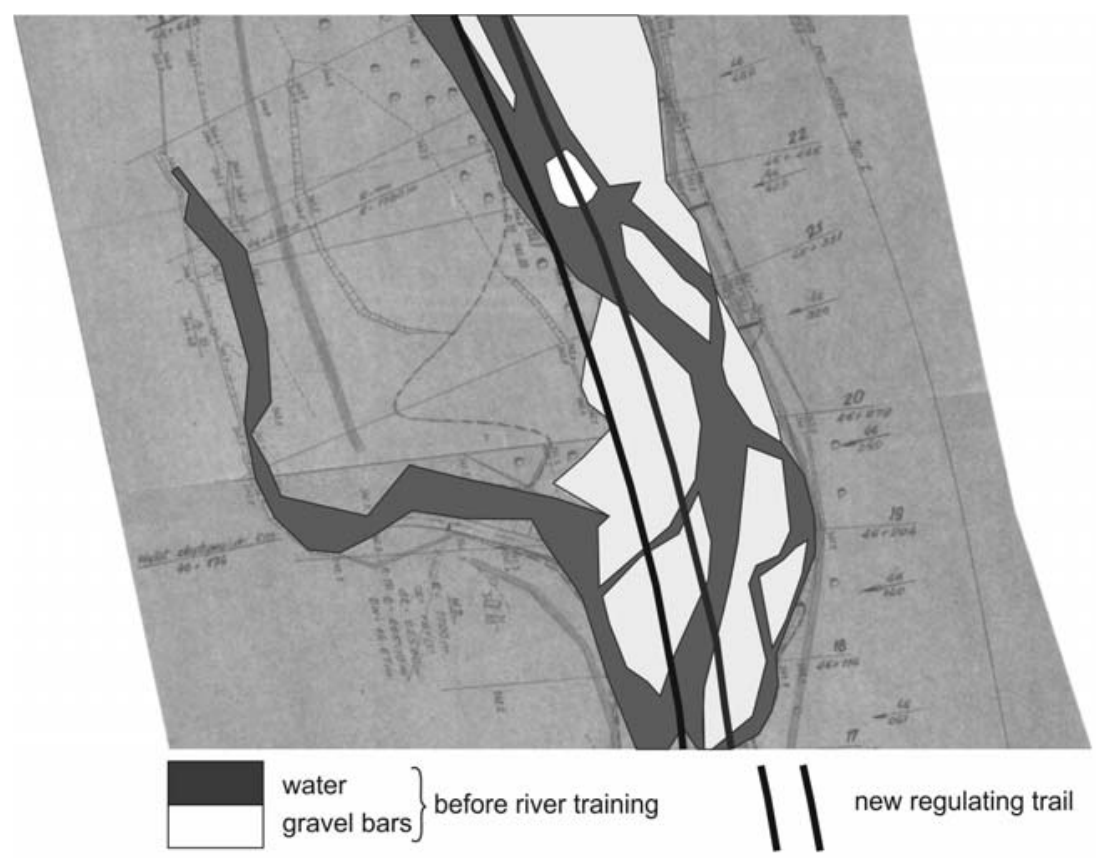

FIGURE 5. Regulated channel of the Skawa river compared to its braided channel (Regulacja rzeki Skawy w m. Sucha - Maków Podchalański, 44+750-49+600 km, 1976, Okręgowa Dyrekcja Gospodarki Wodnej, Kraków)

such channel straightening, shortening and narrowing, the stream gradient has increased and water flow accelerated, leading to increased transport of material and the lowering of riverbed levels.

The channel deepening process increased greatly after WWII as a result of debris extracted directly from the channel. The extraction proceeded on a large (mass) scale using excavators, but also as a result of the collection of maximum-fraction rocks (individual extraction) for construction purposes. Consequently, armour was removed and channel deepening took place along the affected sections. The changes extended to the neighbouring reaches as a result of headward erosion. Mass and long-lasting extraction caused the channels to deepen fast, gradually exposing the underlying bedrock (Krzemień 2003, Kościelniak 2004, Zawiejska 2006). Such transformation took place e.g. in the channel of the Ropa river, where industrial exploitation of gravels caused the river to cut in to a depth of $1.5 \mathrm{~m}$, with resultant upstream and downstream erosion changing several tens of kilometres of alluvial channel into rock channel (Augustowski 1968). The practice affected most Carpathian river channels with the greatest impact taking place in the 1970s (Krzemień 1984, Klimek 1987, Wyżga 1991). At present, such activity is banned by law. Unfortunately, illegal extraction continues in the channels of the Czarny Dunajec, the Skawa and the Raba rivers.

In some channels "minor" contingency works are undertaken with the consent of the Regional Water Management 
Authority to provide "ad-hoc flood prevention and protection of human life, health and property in riverbank towns" (Gorczyca et al. 2011). The work involves displacement of gravel material needed to build dams for mill races and removal of channel bars in order to redirect the main stream towards the middle of the channel. This kind of work also leads to the dissection of islands and large bars. The decisions have an adverse effect as they permanently dissect alluvia and accelerate erosion of alluvial channels. Such activity has been detected in the channel of the Białka River, which is formally protected as a natural reserve and a Natura 2000 site.
As a result of all the above human activity, channel systems keep changing at a slower or faster rate. The channels of the Carpathian rivers become ever straighter and narrower (Figs 6,7). Braided channels with a tendency to lateral migration have been narrowed and incised by as much as 2-4 m (Klimek 1987, Łapuszek, Ratomski 2006, Zawiejska, Wyżga 2010). Once their training structures are destroyed or as soon as previous intensive human impact stops, rivers recover their capacity to shape their channels freely. However, being incised as deep as they are, such channels cannot return to their pre-regulation sta-

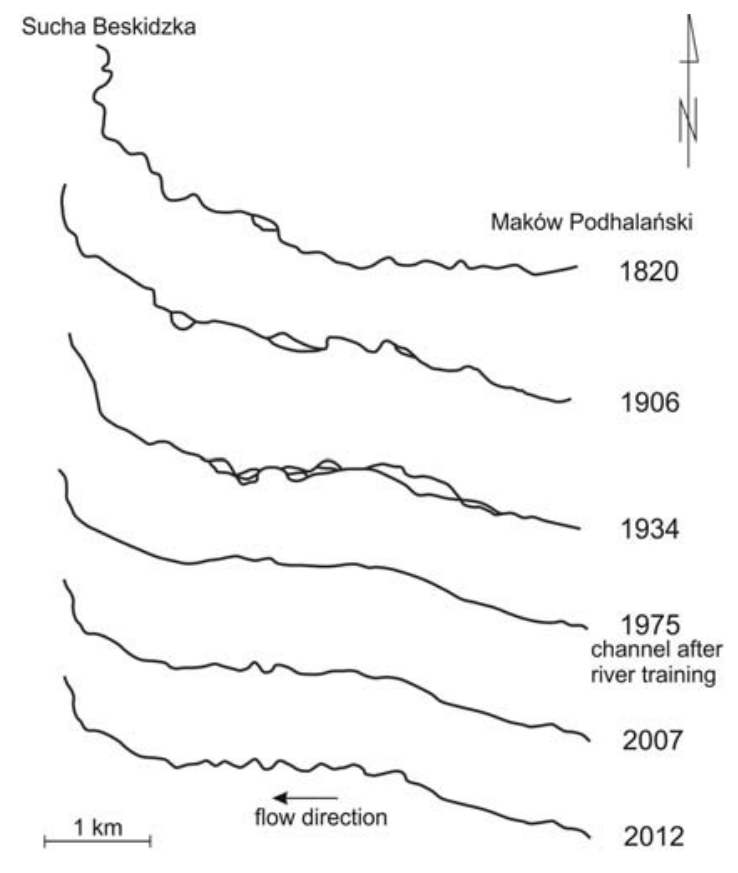

FIGURE 6. Development of the channel morphology of the Skawa river between Maków Podhalański and Sucha Beskidzka in the years 1820-2012 (1820 - Семитопографическая Карта Царства Польского, Karta Galicji, 1 : 125 000; 1906 - Specialkarte der k.u.k. österreichisch-ungarischen Monarchie in Mafsstabe 1:75 000 der Natur, K.u.k. Militärgeographisches Institut; 1934 - Mapa Wojskowego Instytutu Geograficznego, 1934, 1 : 100 000, arkusz Babia Góra, Warszawa; 1975 - Mapa topograficzna, $1: 25$ 000, Główny Geodeta Kraju, Warszawa; 2007 and 2012 - orthophotos, Centralny Ośrodek Dokumentacji Geodezyjnej i Kartograficznej, Warszawa) 


\section{A}

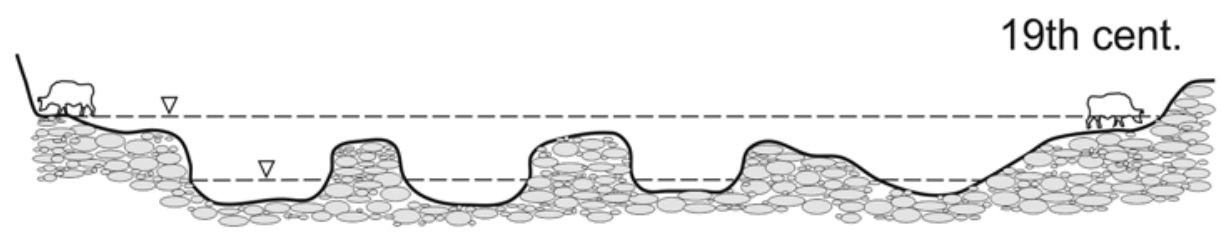

B

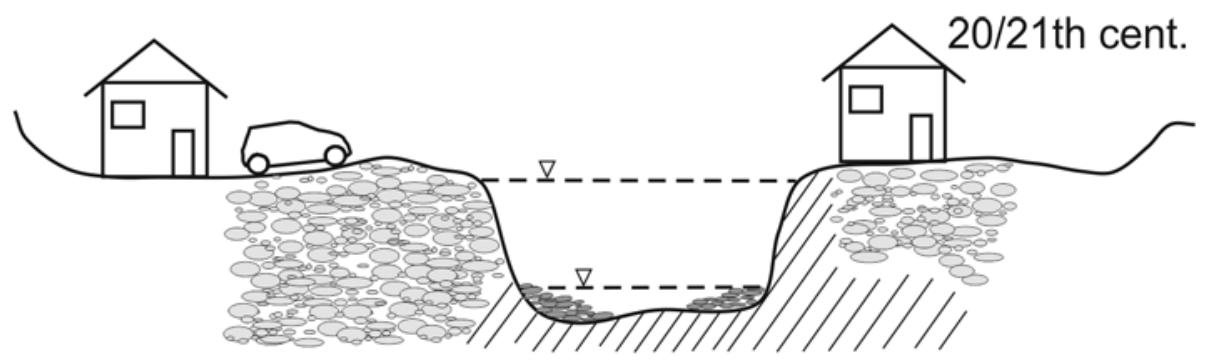

FIGURE 7. Development of the Carpathian river channels

tus (Fig. 7). They develop further within a much narrower area.

\section{CONCLUSIONS}

In areas with high human impact, rivers and streams adjust the channel system structure to the changing conditions on valley floors and on valley slopes. Such changes mainly cause the narrowing and deepening of entire channel systems. The main underlying causes of river channel changes are: land use and infrastructural changes in catchment areas as well as direct human impact in the river channels. Generally, this limits the possibility of free development of the channel course. In consequence, narrow channels are created, most of which have the capacity for high episodic flows. Channels of major rivers have been deepened in the last few decades by as much as $2-4 \mathrm{~m}$. As a result of headward erosion, channels also tend to deepen in hanging valleys. The above situation leads to adverse changes of the natural environment in valley floors linked to excessive drying of many areas. Environmental and economic problems have started to appear on the valley floors. Old trees have started to die out on low floodplain terraces. Wells dry up.

Fluvial processes in the channels of Carpathian rivers and streams are relatively slow. Rapid change only tends to occur during extreme episodic flows. As a rule, extreme episodic flows are relatively infrequent, however, they make a great contribution to the development of the Carpathian valley floors. Channel systems respond to extreme flows, and frequently exceed the threshold values, which causes channels forms to change. 


\section{REFERENCES}

AUGUSTOWSKI B. 1968: Spostrzeżenia nad zmianami antropogenicznymi w korycie rzeki Ropy w Karpatach (Observations on man-caused changes in the channel of the River Ropa in the Carpathians). Zeszyty Geograficzne WSP w Gdańsku 10, 161-168 [Eng. summ.].

BAUGMART-KOTARBA M., KOTARBA A. 1979: Wpływ rzeźby dna doliny i litologii utworów czwartorzędowych na wykształcenie koryta Białej Wody w Tatrach (Influence of the landscape of a valley bottom and the lithology of Quaternary formations on the development of the Biała Woda River channel in the Tatra Mountains). Folia Geographica, Series Geographica-Physica 12, 49-66 [Eng. summ.].

CHEŁMICKI W., KRZEMIEŃ K. 1999: Channel typology for the River Feshie in the Cairngorm Mts., Scotland. Prace Geograficzne IGUJ 104, 57-68.

GĘBICA P., PATKOWSKI B., LASEK A., SOKOŁOWSKI T. 1998. Geomorfologiczne i sedymentologiczne skutki przerwania wałów przeciwpowodziowych w dolinie Wisły w lipcu 1997 roku (Geomorphic and Sedimentological Effects of a Break in the Embankments in the Vistula valley in July 1997). In: L. Starkel, J. Grela (Eds), Powódź w dorzeczu górnej Wisły w lipcu 1997 roku. Kraków, 185-194 [Eng. summ.].

GORCZYCA E. 2012: Struktura i morfodynamika koryta Łososiny (Beskid Wyspowy). Przykład opracowania (Structura and morphodynamics of Łososina River channel - Beskid Wyspowy Mts. Case study). In: K. Krzemień (Ed.), Struktura koryt rzek i potoków (studium metodyczne). Instytut Geografii i Gospodarki Przestrzennej UJ, Kraków, 79-88.

GORCZYCA E., KRZEMIEŃ K., ŁYP M. 2011: Contemporary trends in the Białka River channel development in the Western Carpathians. Geographia Polonica 84, Special Issue Part 2, 39-53.
GORCZYCA E., KRZEMIEŃ K., WROŃSKA-WAŁACH D., SOBUCKI M. 2013: Channel changes due to extreme rainfalls in the Polish Carpathians. In: D. Lóczy (Ed.), Geomorphological impacts of extreme weather. Springer, Amsterdam, 23-35.

IZMAIŁOW B., KAMYKOWSKA M., KRZEMIEŃ K. 2006: The geomorphological effects of flash floods in mountain river channels. The case of the River Wilsznia - Western Carpathian Mountains. Prace Geograficzne IGiGP UJ 116, 89-97.

IZMAIŁOW B., KRZEMIEŃ K., SOBIECKI K. 2009: Rzeźba i jej współczesne przemiany (Relief and its contemporary changes). In: A. Górecki, B. Zemanek (Eds), Magurski Park Narodowy - Monografia Przyrodnicza. Krempna-Kraków, 23-43.

KAMYKOWSKA M., KASZOWSKI L., KRZEMIEŃ K. 1999: River channel mapping instruction, Key to the river bed description. Prace Geograficzne IG UJ 104, 9-25.

KAMYKOWSKA M., KASZOWSKI L., KRZEMIEŃ K. 2012: Kartowanie koryt rzecznych (River channel mapping). In: K. Krzemień (Ed.), Struktura koryt rzek i potoków (studium metodyczne). IGiGP UJ, Kraków, 15-35.

KASZOWSKI L. 1973: Morphological activity of the mountain streams - with Biały Potok in the Tatra Mts. as example. Zeszyty Naukowe UJ, Prace Geograficzne 31, 1-101.

KASZOWSKI L. 1979: Dynamiczna typologia koryt rzecznych na obszarze Karpat i ich przedgórza (Dynamic typology of river channels in the Carpatian Mts. and their foreland). Sprawozdania $z$ Posiedzeń Komisji Naukowych PAN 21(1), 149-150.

KASZOWSKI L., NIEMIROWSKI M., TRAFAS K. 1976: Problems of the dynamics of river channels in the Carpathian part of the Vistula basin. Zeszyty Naukowe UJ., Prace Geograficzne 43, 7-37. 
KASZOWSKI L., KRZEMIEŃ K. 1977: Structure of mountain channel systems as examplified by chosen Carpathians streams. Studia geomorph. Carpatho-Balcan. 11, 111-125.

KASZOWSKI L., KRZEMIEŃ K. 1999: Classification systems of mountain river channels. Prace Geograficzne IG UJ 104, 27-40.

KLIMEK K. 1979: Geomorfologiczne zróżnicowanie koryt karpackich dopływów Wisły (Morphodynamic channel types of the Carpathian tributaries to the Vistula). Folia Geographica Series Geographica-Physica 12, 35-47 [Eng. summ.].

KLIMEK K. 1987: Man's impact on fluvial processes in the Polish Western Carpathians. Geografiska Annaler 69A, 221-226.

KORPAK J. 2012: Morfologia i funkcjonowanie uregulowanego koryta rzeki górskiej - na przykładzie Mszanki w Gorcach. Przykład opracowania (Morphology and functioning of regulated mountain river channel - Mszanka River in the Gorce Mts.). Case study). In: K. Krzemień (Ed.), Struktura koryt rzek i potoków (studium metodyczne). Instytut Geografii i Gospodarki Przestrzennej UJ, Kraków, 89-101.

KORPAK J., KRZEMIEŃ K., RADECKI-PAWLIK A., 2008: Wpływ czynników antropogenicznych na zmiany koryt cieków karpackich (Influence of anthropogenic factors on changes in the Carpathian stream channels). Infrastruktura $i$ ekologia terenów wiejskich. Monografia 4, PAN, Kraków [Eng. summ.].

KOŚCIELNIAK J. 2004: Influence of river training on functioning of the Biały Dunajec River channel system. Geom. Slovaca 4(1), 62-67.

KRZEMIEN' K. 1984: Współczesne zmiany modelowania koryt w Gorcach (Contemporary changes of river channels modeling in the Gorce Mts.). Zeszyty Naukowe UJ, Prace Geograficzne 59, 83-96.

KRZEMIEŃ K. 1999: Structure and dynamics of the high-mountain channel of River Plima in the Ortler-Cevedale Massif
(South Tirol). Prace Geograficzne IGUJ 104, 41-55.

KRZEMIEŃ K. 2003: The Czarny Dunajec River, Poland, as an example of human induced development tendencies in a mountain river channel. Landform Analysis 4, 57-64.

KRZEMIEŃ K. (Ed.), 2012: Struktura koryt rzek i potoków. Studium metodyczne Structure of river and stream channels. (Methodical study). Instytut Geografii i Gospodarki Przestrzennej UJ, Kraków, $1-144$.

LACH J. 1999: Współczesne tempo erozji wgłębnej w dorzeczu górnej Wisłoki (Present rate and size of deep erosion in the upper Wisłoka River drainage basin). Interdyscyplinarność w badaniach dorzecza. Instytut Geografii UJ, Kraków, 219-229.

ŁAPUSZEK M., RATOMSKI J. 2006: Metodyka określania i charakterystyka przebiegu oraz prognoza erozji dennej rzek górskich dorzecza górnej Wisły (The method of establishing, characteristics and forecasting of the riverbed erosion of the upper Vistula basin mountainous rivers). Inżynieria Środowiska 332.

ŁYP M. 2012: Parametry morfometryczne zlewni i koryt rzecznych w badaniach systemu fluwialnego (Morphometric parameters of catchments and river channels in fluvial system research). In: K. Krzemień (Ed.), Struktura koryt rzek i potoków - studium metodyczne. Instytut Geografii i Gospodarki Przestrzennej UJ, Kraków, 43-53.

NIEDŹWIEDŹ T., OBRĘBSKA-STARKLOWA B. 1991: Klimat (Climate). In: I. Dynowska, M. Maciejewski (Eds), Dorzecze górnej Wisły, Cz. I (Upper Wisla River drainage basin. Vol. II) PWN, Warszawa-Kraków, 58-84 [Eng. summ.].

SOJA R. 1977: Deepening of channel in the light of the cross profile analysis. Carpathian river as example. Studia Geomorphologica Carpatho-Balcanica 11, 127-138. 
STARKEL L., LAJCZAK A. 2008: Kształtowanie rzeźby den dolin w Karpatach - koryt i równin zalewowych [Modeling of valley bottoms in the Carpathian Mts. (channels and floodplains)]. In: L. Starkel, A. Kostrzewski, A. Kotarba, K. Krzemień (Eds), Współczesne przemiany rzeźby Polski. IGiGP UJ, Kraków, 95-108.

TRAFAS K. 1975: Zmiany biegu koryta Wisły na wschód od Krakowa w świetle map archiwalnych i fotointerpretacji (Changes of the Vistula River Bed east of Cracov in the light of archival maps and photointerpretation). Zeszyty Naukowe UJ, Prace Geograficzne 40, 1-85 [Eng. summ.].

WROŃSKA-WAŁACH D., PŁACZKOWSKA E., KRZEMIEŃ K. 2013: Leje źródłowe jako systemy morfodynamiczne w obszarach górskich (Morphodynamic system of mountain headwater areas). Przeglad Geograficzny 85, 1, 31-51 [Eng. summ.].

WYŻGA B. 1991: Present-day downcutting of the Raba River channel - Western Carpathians, Poland - and its environmental effects. Catena 18, 551-566.

WYŻGA B. (Ed.) 2008: Stan środowiska rzek południowej Polski i możliwości jego poprawy-wybrane aspekty (Environmental significance, degradation and possibilities of restoration of multithread rivers in southern Poland). Instytut Ochrony Przyrody PAN, Warszawa [Eng. summ.].

ZAWIEJSKA J. 2006: Struktura i dynamika koryta Dunajca. Rozprawa doktorska (Structure and dynamics of the Dunajec River channel. Doctoral thesis). Archiwum IGiGP UJ, 1-179.

ZAWIEJSKA J., KRZEMIEŃ K. 2004: Man-induced changes in the structure and dynamics of the Upper Dunajec River channel. Geografický Časopiss 56 (2), 111-124.

ZAWIEJSKA J., WYŻGA B. 2010: Twentieth-century channel change on the Dunajec River, southern Poland: Patterns, causes and controls. Geomorphology 117 (3), 234-246.
ZAWORA T. 1967: Współczesne procesy fluwialne w korycie Hoczewki (Contemporary fluvial processes in the Hoczewka river bed). Studia Geomorphologica Carpatho-Balcanica 1, 35-50.

Streszczenie: Funkcjonowanie koryt rzek górskich pod wplywem przemian środowiska przyrodniczego i antropopresji, Karpaty, poludniowa Polska. W Karpatach i na ich przedpolu ma miejsce współcześnie znaczące przeobrażanie koryt rzek i potoków głównie pod wpływem antropopresji. Przeobrażenia te są uwarunkowane zmianami użytkowania $\mathrm{w}$ dorzeczach oraz bezpośrednią ingerencją w korytach (eksploatacja rumowiska, zabudowa hydrotechniczna, prostowanie koryt). W wyniku oddziaływań antropogenicznych następują znaczące zmiany struktury systemów korytowych prowadzące do wzrostu znaczenia erozji. Prowadzi to głównie do skanalizowania systemu fluwialnego. Artykuł jest przeglądem badań nad strukturą i dynamiką koryt rzek karpackich opartych na metodyce zbierania informacji o całych systemach korytowych. Zastosowano raptularz i instrukcję wypracowaną w Zakładzie Geomorfologii Instytutu Geografii i Gospodarki Przestrzennej Uniwersytetu Jagiellońskiego.

Stowa kluczowe: przemiany struktury koryt, koryta rzek karpackich, antropopresja

\author{
Authors' address: \\ Kazimierz Krzemień, Elżbieta Gorczyca, \\ Mateusz Sobucki, Maciej Liro, Michał Łyp \\ Instytut Geografii i Gospodarki Przestrzennej \\ Uniwersytet Jagieloński \\ ul. Gronostajowa 7 \\ 30-387 Kraków, Poland \\ e-mail: kazimierz.krzemien@uj.edu.pl \\ elzbieta.gorczyca@uj.edu.pl \\ mateusz.sobucki@uj.edu.pl \\ maciej.liro@uj.edu.pl \\ michal.lyp@gmail.com
}

